DOI: $10.17805 /$ trudy.2018.4.4

\title{
ОСОБЕННОСТИ МОТИВАЦИИ УЧЕБНОЙ ДЕЯТЕЛЬНОСТИ СТУДЕНТОВ ВУЗА ПЕРВОГО И ЧЕТВЕРТОГО КУРСОВ (СРАВНИТЕЛЬНЫЙ АНАЛИЗ)
}

\author{
Е. Е. Иванова \\ Московский гуманитарный университет, \\ Ю. А. Сторожева
}

Астраханский государственный медицинский университет Минздрава РФ

Аннотация: Статья посвящена исследованию особенностей мотивов учебной деятельности студентов вуза. Были выявлены мотивы учебной деятельности студентов заочной формы обучения 1-го и 4-го курсов, обучающихся по направлению подготовки «Психолого-педагогическое образование» в Московском гуманитарном университете.

Ключевые слова: мотивация учебной деятельности; высшее образование; мотивация; учебная деятельность

\section{PECULIARITIES OF MOTIVATION OF EDUCATIONAL ACTIVITY OF FIRST AND FOURTH YEAR STUDENTS (COMPARATIVE ANALYSIS)}

\author{
E. E. Ivanova \\ Moscow University for the Humanities, \\ Y. A. Storozheva \\ Astrakhan State Medical University
}

Аннотация: The article is devoted to the study into the peculiarities of the motives of university students' educational activity. The authors reveal motives of educational activity of first and fourth year students of the extramural form of study specializing in «Psychological and pedagogical education» at Moscow University for the Humanities.

Ключевые слова: motivation of educational activity; higher education; motivation; educational activity

\section{Введение}

Современное общество предъявляет все более высокие требования к будущему специалисту - умение мыслить, решать нестандартные задачи и находить альтернативные оптимальные решения, осмысливать последствия своей деятельности для себя и окружающих. Главной движущей силой такого поведении и деятельности является мотивация. Поэтому вопрос о мотивах учебно-профессиональной деятельности студентов приобретает особое значение. 
Научные труды Московского гуманитарного университета 2018 № 4

Мотивы рассматриваются как одна из мобильных систем, на которую можно оказывать влияние. Даже если, выбирая будущую профессию, студент выбор сделал не вполне самостоятельно, не в полной мере осознавая перспективы, то, формируя или изменяя устойчивую систему мотивов деятельности, можно помочь будущему специалисту в профессиональной адаптации и профессиональном становлении. Анализируя динамику мотивов учения в процессе овладения будущей профессией, можно корректировать мотивы учения и влиять на профессиональное становление студентов.

\section{К теории вопроса о мотивации учебной деятельности}

В настоящее время изучение проблемы мотивации учебной деятельности студентов, динамики ее становления в процессе обучения в вузе является комплексным и осуществляется на «стыке» психологии личности (К. А. Абульханова, Б. Г. Ананьев, Л. И. Анциферова, В. Г. Асеев, Б. Ф. Ломов, С. Л. Рубинштейн и др.), психологии развития (Л. И. Божович, А. В. Петровский и др.), психологии труда и профессий (Е. М. Борисова, Г. Г. Голубева, К. К. Платонов и др.), акмеологии (А. А. Бодалев, А. В.Зобков, В. Г. Зазыкин, А. А. Деркач, Н. В. Кузьмина, И. П. Краснощеченко, А. А. Реан, Н. П. Фетискин и др.).

А. В. Белошицкий мотивацию учебной деятельности рассматривает как «совокупность отношений студента к учению (к различным аспектам учебного процесса), как к средству достижения целей обучения, ориентированных на процесс познания (познавательные мотивы), на результат (мотивы достижения), на вознаграждение и на избегание наказаний (прагматические мотивы)» (Белошицкий, 2007: 126).

Факторы, которые могут способствовать формированию мотивации учебной деятельности студентов, делятся на две группы: объективные, отражающие особенность самой организации образовательного процесса, привлекательность вуза, специфику учебных дисциплин, и субъективные, характеризующие индивидуально-психологические особенности студентов и уровень сформированности у них учебно-профессиональной мотивации в довузовский период, а также личностные особенности преподавательского состава, его отношение к обучающимся и к своей профессии в целом (Селиверстова, 2014: Электр. ресурс).

Соотношение познавательных и профессиональных мотивов в структуре учебной мотивации студентов, по мнению Н. А. Бакшаевой, А. А. Вербицкого, состоит в следующем:

- познавательные и профессиональные мотивы рассматриваются как противоположные в иерархической структуре мотивов учения студентов; доминирование профессиональных мотивов над познавательными может привести к узкой специализации студента, вынуж- 
денному ограничению кругозора будущего профессионала, по этой причине познавательные и профессиональные мотивы выступают как взаимоисключающие в развитии структуры мотивации учебно-профессиональной деятельности студентов;

- профессиональные мотивы имеют статус ведущих в мотивации учебно- профессиональной деятельности студента, поскольку профессиональные мотивы более активно влияют на эффективность учебно-профессиональной деятельности студентов;

- имеет место взаимосвязь познавательных и профессиональных мотивов: преобладание в структуре познавательных интересов студента специфических, направленных на предмет будущей профессиональной деятельности, служит показателем сформированности профессиональной направленности (Бакшаева, Вербицкий, 2013).

Мотивация, связанная с профессиональным интересом в процессе овладения профессией, выступает в качестве ресурса и предпосылки для становления профессионала. Для студента важны устойчивые профессиональные мотивы учебной деятельности и вполне адекватные представления о своей будущей работе. В этом случае обучающиеся будут стремиться к постоянному развитию креативности, нацеленной на получение нового знания и формирования профессионально важных качеств (там же).

Профессиональные мотивы по существу являются видоизмененными мотивами выбора профессии, поскольку зависят от того, как произошло знакомство с профессией, как организован образовательный процесс в конкретном вузе. В процессе обучения мотивационная сфера студентов меняется: появляются новые мотивы, претерпевают изменения сформированные, происходит переоценка значения отдельных мотивов, изменение структуры мотивов.

\section{Особенности изменений мотивации учебной деятельности в период обучения в вузе}

Развитие профессионально-ориентированной мотивации студентов определяется динамикой развертывания содержания деятельности студентов — собственно академической, квазипрофессиональной, учебно-профессиональной.

Ю. П. Поваренков, исследуя основные периоды и фазы становления профессионально-ориентированной мотивации в процессе обучения, пришел к выводам, что социальная ситуация профессионального развития является основным механизмом профессионализации. Опираясь на данное положение, автор выделяет 2 этапа обучения студентов в вузе. Первый этап называется учебно-академический (1-3 курсы), второй - учебно-профес- 
Научные труды Московского гуманитарного университета 2018 № 4

сиональный (4-5 курсы). Указанные этапы во многом отличаются друг от друга, это и определяет неравномерное, скачкообразное развитие процесса профессионализации студентов. Первый этап - это адаптация к условиям и содержанию образовательного процесса с вузе, а также освоение новой социальной роли студента, выстраивание акмеологической технологии взаимоотношений с преподавателями и обучающимися. Высокий уровень сформированности познавательных мотивов и мотивов личного самоопределения свидетельствует об успешном прохождении данной стадии. Учебно- профессиональный этап называют этапом интенсификации, во время которого студент адаптировался к новым условиям академической деятельности, в связи с чем, лидирующую позицию занимают мотивы личностного развития, построения семьи и т. д. Чаще всего именно в этот период у студентов меняется отношение к процессу овладения будущей профессией (Поваренков, 1991: 126).

Исследователями отмечается, что на стадии профессионального образования студенты часто переживают разочарование в получаемой профессии. Появляется неудовлетворенность некоторыми дисциплинами, сомнение в правильности сделанного профессионального выбора. Студентам становится неинтересен процесс обучения. Наблюдается так называемый кризис профессионального выбора, который в наибольшей степени проявляется на первом и выпускном курсах профессионального обучения.

Изучение мотивации учебной детальности студентов, проведенные в различных высших учебных заведениях России, наглядно демонстрируют, что лишь у небольшого количества студентов в качестве ведущих мотивов учебной деятельности выступают познавательный и профессиональный мотив: от 8\% до 38\%. Разница в величине зависит от направлений подготовки, престижа учебного заведения, пола респондентов и т. п. Нет оснований утверждать, что количество высокомотивированных студентов намного увеличивается с первого курса по четвертый курс. В ряде исследованиях было обнаружено некоторое уменьшение доли высокомотивированных студентов, в других - зафиксирована ее неизменность, в третьих - увеличение.

В процессе обучения мотивационная сфера студентов, безусловно, меняется: появляются новые мотивы, претерпевают изменения сформированные, происходит переоценка значения отдельных мотивов, изменение структуры мотивов. В этой связи нами было организовано и проведено пилотажное исследование, с целью изучения и выявления различий в мотивационной основе учебной деятельности у студентов первого и четвертого курсов, обучающихся по направлению подготовки «Психолого-педагогическое образование».

В исследовании приняли участие две группы студентов факультета пси- 
хологии, педагогики и социологии АНО ВО «Московский гуманитарный университет», направления подготовки «Психолого-педагогическое образование»: 1 курс - 10 человек, и 4 курс - 10 человек, обучающихся по заочной форме обучения. Для исследования мотивации учебной деятельности студентов была использована методика «Диагностика мотивов учебной деятельности студентов» А. А. Реан и В. А. Якунина в модификации Н. Ц. Бадмаевой.

Результаты исследования показали, что для студентов 1 курса лидирующими являются мотивы творческой самореализации, менее выражены мотивы профессиональные и коммуникативные, остальные и вовсе не играют существенной роли, тогда как для студентов 4 курса лидирующими мотивами являются профессиональные, что говорит о заинтересованности выпускников в стремлении совершенствоваться в качестве высококвалифицированного специалиста. Коммуникативные и социальные мотивы тоже играют для них существенную роль, студенты 4 курса осознают ценность знаний в обществе и именно они являются способом социализации в коллективе.

Сравнивая эти две категории опрошенных можно сделать вывод о том, что для всех студентов и 1 и 4 курсов в равной степени знания являются средством достижения целей, успехов, как в плане привнесения пользы обществу, так и карьерного роста и материального обеспечения. Одновременно на последнем месте оказались мотивы престижа и избегания, это говорит о том, что студенты не желают конкурировать со своими сокурсниками, а также независимы от общественного мнения. В этом выражается внутреннее убеждение в выборе профессиональной деятельности и стремление получать знания исходя из собственных целей и предпочтений.

Применять получаемые знания и оперировать ими в новых знакомствах и беседах с разными интересными людьми выпускники считают более весомыми мотивами, чем первокурсники. Последние, в то же время, еще не потеряли инициативности привнесения в деятельность педагога новых течений, поэтому студентам 1 курса гораздо важнее самореализоваться творчески.

Данные исследования показали, что учебно-познавательные мотивы у студентов 4 курса становятся менее значимыми. Возможно, это связано с тем, что респонденты не получают удовлетворения от самого процесса обучения и получения новых знаний, а также не видят себя в качестве научных деятелей. Выпускники более ориентированы на практическую деятельность.

\section{Выводы}

Исходя из вышесказанного, можно говорить о разных приоритетах в определении мотивов: так студенты 1 курса делают акцент на творческой инициативе и научной стороне преподавательской деятельности, студенты 
4 курса определяют наиболее значимыми социальные аспекты профессии. Данная ситуация может быть обусловлена тем, что в исследовании принимали участие студенты, обучающиеся по заочной форме обучения. Почти все они состоят в трудовых отношениях и выбор профессии был сделан осознано, тем интереснее было проанализировать мотивацию профессиональной деятельности. Для этого мы использовали методику «Мотивация профессиональной деятельности» (К. Замфир в модификации А. Реан), которая показала, что для всех современных студентов внутренняя мотивация играет большую роль при выборе профессии и стремлении достижения в ней определенных результатов, а также особо важно внутреннее удовлетворение от данной деятельности.

Различия происходят в типах внешней мотивации. Здесь мы наблюдаем боязнь первокурсников получить негативную критику или оценку их работы, большее нежелание преодолевать наказания и неприятности. Будущие выпускники уделяют внимание именно положительным факторам, так как приходит осознание значимости социального статуса, престижа, важности заработка и продвижения по карьерной лестнице. Понятно что, студенты первого курса не всегда способны эмоционально устоять в процессе психолого-педагогической деятельности, тем самым не всегда им удается повысить эффективность собственной работы.

В процессе профессионального обучения, за счет формирования профессиональных компетенций, профессионально значимых качеств, происходит переломный момент в мотивационной основе учебной деятельности студента педагога-психолога, что позволяет ему выстроить собственный устойчивый и оптимальный мотивационный комплекс профессиональной деятельности, стать саморазвивающимся и конкурентоспособным работником.

\section{СПИСОК ЛИТЕРАТУРЫ}

Бакшаева, Н. А., Вербицкий А. А. (2013) Психология мотивации студентов : учеб. пособие для вузов. М. : Логос. 183 с.

Белошицкий, А. В. (2007) Детерминанты профессионального развития курсантов // Мир образования - образование в мире. № 1. С. 125-131.

Поваренков, Ю. П. (1991) Психология профессионального становления личности Курск: КРОСТ. 132 с.

Селиверстова, С. Ю. (2014) Акмеологические условия формирования учебно-профессиональной мотивации студентов вуза экономико-управленческого профиля [Электронный ресурс] // Гуманитарные, социально-экономические и общественные науки. № 5. URL: http://online-science. ru/userfiles/file/jkyrmaiqc8t229uhfpdb3kyuq1hx0rwz.pdf (дата обращения: 12.08.2018).

Дата поступления: 15.08.2018 2. 
Иванова Екатерина Евгеньевна - кандидат психологических наук, доцент кафедры педагогики и психологии высшей школы Московского гуманитарного университета. Адрес: 111395, Россия, г. Москва, ул. Юности, д. 5. Тел.: +7 (499) 374-74-59. Эл. адрес: pp.mosgu@mail.ru

Сторожева Юлия Анатольевна - кандидат психологических наук, доцент кафедры психологии и педагогики Астраханского государственного медицинского университета Минздрава России. Адрес: 414000, Россия, г. Астрахань, ул. Бакинская, д. 121. Эл. адрес: efterpa@bk.ru

Ivanova Ekaterina Yevgenyevna, Candidate of Psychology, Associate Professor, Department of Pedagogy and Psychology of Higher School, Moscow University for the Humanities. Postal address: 5, Yunosti St., Moscow, Russian Federation, 111395. Tel.: +7 (499) 374-74-59. E-mail: pp.mosgu@mail.ru

Storozheva Yulia Anatolyevna, Candidate of Psychology, Associate Professor, Department of Psychology and Pedagogy, Astrakhan State Medical University. Postal address: 121, Bakinskaya St., Astrakhan, Russian Federation, 414000. E-mail: efterpa@bk.ru

\section{Для цитирования:}

Иванова Е. Е., Сторожева Ю. А. Особенности мотивации учебной деятельности студентов вуза первого и четвертого курсов (сравнительный анализ) [Электронный ресурс] // Научные труды Московского гуманитарного университета. 2018. № 4. URL: http://journals.mosgu.ru/trudy/article/view/808 (дата обращения: дд.мм.гг.). DOI: 10.17805/trudy.2018.4.4 